\title{
William Keit and the Durban Botanic Garden
}

\author{
D. P. McCRACKEN*
}

Keywords: biography, Durban Botanic Garden, William Keit

\section{ABSTRACT}

William Keit was born in Saxony in 1841 and in early life travelled across Europe working in many famous nurseries and gardens. In 1872 on the recommendation of the director of Kew Gardens, Keit emigrated to Natal to become curator of the Durban Botanic Garden. So dilapidated was this garden that Keit was faced with the task of virtually re-establishing it. Though he was largely successful in this endeavour, as he was in fortifying the link between Natal and Kew, Keit could not solve the problems of a severe drought, a labour shortage and a scarcity of funds. In 1881 he resigned his position leaving a solid foundation on which the renowned botanist, John Medley Wood was to build. Keit in later life ran a successful nursery in Durban and for 30 years was curator of the Parks and Gardens Department, in which capacity he did more than anyone else to beautify Durban.

\section{The early Botanic Garden}

In April 1848 the Natal Agricultural and Horticultural Society was founded in Durban with the principal aim of establishing a botanic garden to serve the young colony of Natal (Natal Agricultural and Horticultural Society 1848). It was not until June 1851, however, that a permanent site of some 50 acres on the lower slopes of the Berea was taken over by the Horticultural Society (Durban City Estates Department n.d.). Though in the next 20 years the garden spearheaded crop experimentation and seed distribution, it was never properly developed into a botanic garden. It remained largely virgin bush, unfenced save for a small allotment area.

Because the curator's salary was so low, the Society had difficulty in finding a suitable man for the post. Between 1851 and 1872 there were seven curators (Strey n.d.). The best known and the longest serving of these was a Scot named Mark Johnston McKen who was curator from 1851 to 1853 and again from 1860 to 1872 (Natal Colonist 23 April 1872; Natal Mercury 25 April 1872). McKen did much for the economic development of Natal but failed to lay out a proper botanic garden. When he died in March 1872 , leaving his wife and six children destitute, the Horticultural Society resolved to employ a curator who, unlike McKen, would devote his whole energies to the garden. As they could find no one suitable in the colony they wrote to Sir Joseph Hooker, the director of the Royal Botanic Gardens at Kew, requesting him to recommend a replacement for McKen (Natal Government Notice No. 191; 1872). Hooker had recently been impressed by a young German gardener named Julius Wilhelm Keit, or William Keit as he called himself in the Englishspeaking world, who at the time was employed at the Royal Botanic Gardens, Glasnevin, outside Dublin (Strey 1972; 1974).

\section{Keit's early career}

William Keit was born in Dresden in the state of Saxony on 1 May 1841. He was the son of a master

\footnotetext{
* University of Durban-Westville, Private Bag X54001, Durban 4000 , South Africa.
}

soap-maker (Pers. comm.: Frl. Klara Keit, Mannheim, W. Germany). His father died when he was young and Keit inherited a small sum which was administered until he came of age by his uncle and guardian, Hermann Steinmetz. As a young man, Keit led a somewhat carefree if lonely life. Having been sacked from his first job, he moved across Europe working in gardens and nurseries in Munich, Basle, possibly Paris, in Linden's nursery in Brussels, the Exhibition Palace winter gardens in Dublin and in the gardens of Blyth Hall in Nottinghamshire, England. Finally, in June 1868, he was appointed to Glasnevin (Keit n.d.(a)).

Though Keit considered Dublin the dirtiest city he had ever seen, he was fond of Glasnevin and had a great respect for its director, Dr David Moore. In September 1869 he accompanied Moore's two children to a boarding school in Hanover. By 1872 Keit

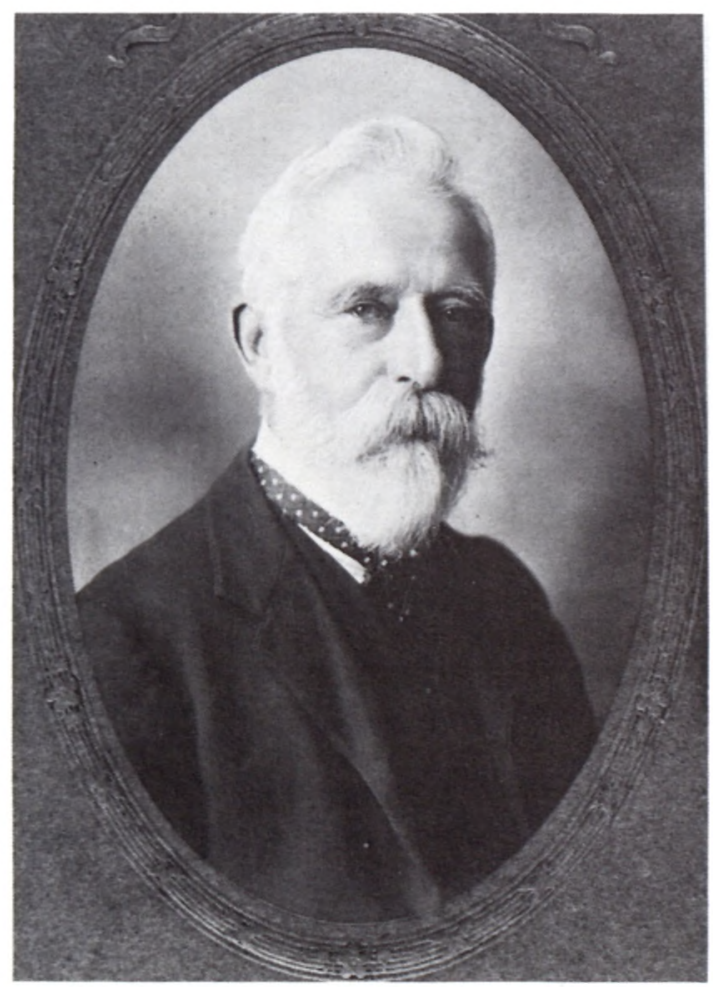

FIG. 1. - William Keit. 
was foreman-in-charge of the propagating houses at Glasnevin (Keit 1867-1869).

When Sir Joseph Hooker received the request from Natal he wrote to Moore asking him his opinion of Keit's suitability for the job. In his reply Moore described Keit as 'an excellent practical gardener and very ingenious at applying various methods for propagating plants' (Moore 1872). A few days later Keit wrote to Hooker expressing his willingness to take the Natal post (Keit 1872a). Hooker duly appointed him.

Six years previously, Keit's cousin Heinrich Hoehne had emigrated to the Cape and Keit had greatly envied him this experience (Keit 1866). Now on 8 September 1872 Keit wrote home excitedly, 'The job in Natal is, according to all accounts, very challenging and I hope I will do justice to it.'

\section{Keit at the Durban Botanic Garden}

Keit left Dublin on 25 September 1872, travelled to see his family in Dresden where he collected a small proportion of his legacy, and returned to England to take ship for South Africa. Hooker presented him with a Wardian case of plants to take to his new garden. Unfortunately, the glass panels on the side of the case were broken on what proved a traumatic voyage and the plants suffered badly. Keit arrived in Natal on 14 December and settled into a 'pretty house' at the foot of the Berea beside the garden. He officially started work on 1 January 1873.

He hid from his benefactor, Dr Moore, his disappointment at the terrible state of the garden and wrote of the great heat, and the beauty of the bougainvillea in full bloom on Christmas day. To Hooker and to his family he was more candid and spoke of his concern about the neglect of the grounds. The garden did have a small and practically empty greenhouse, which had been erected in 1870 , and two summer-houses which afforded panoramic views of the town, the bay and the sea. There was little else to commend the garden. Most of the paths had been washed away and not rebuilt, and what few flowerbeds existed were overgrown. Worse still, in Keit's eyes, was the fact that there was 'no systematic arrangement, the plants having been planted where there was space and, what I regret most, there are no names on them.' He observed, 'it will take me a long time and all my energies to bring something like order in this place and to rename the plants' (Keit 1872b; 1873a; 1873b).

Sir Joseph Hooker soon realized the impossible position Keit was in and offered to try and find him another position elsewhere (Keit 1874). But by then Keit had become engaged to Louisa Currie, the daughter of a prominent Durban citizen and future mayor of the town. The couple were married on 9 September 1874 and were to have eight children. Though this marriage served to hold Keit in Natal he did not dismiss the possibility of emigrating once again. In September 1875 he appealed to Hooker, 'should I fail then I trust you will not forsake me' (Keit 1875).

William Keit did much for the Durban Botanic Garden. By 1874 he had increased the area under cultivation from approximately $4 \frac{1}{2}$ to 9 ha. He fenced the lower part of the garden, laid out flowerbeds, rebuilt the paths, sowed grass on the banks to prevent soil erosion and persuaded the town sanitary department to give him large quantities of manure to improve the quality of the rather poor red soil. He established a proper nursery in 1875 and two years later a pinetum which contained 29 varieties of conifer. He also experimented with wood, zinc and castiron labels to see which could best withstand the destructive combination of white ants and weather. In his annual curator's report for 1877 Keit noted: 'In the absence of any systematic arrangement of plants in the Gardens, it has been my aim, when making fresh plantations to plant individuals of the same order in groups, having regard to effect and situation.'

By the end of 1875 the garden contained 670 plant species. Keit's own interests lay in sea algae, palms, of which he grew 10 species, and cycads. He listed the cycads in his garden as: Cycas media, Encephalartos altensteinii, E. caffra, E. ghellincki, E. hildebrandtii, E. natalensis, E. villosus and Macrozamia tenuifolia (Durban Botanic Garden 1873-1880).

Before he left Glasnevin Keit had written to Hooker: 'My botanical knowledge is more general than particular. I can arrange plants botanically after knowing their names, but I could not undertake to know or describe new plants scientifically.' In the Durban Botanic Garden Keit's taxonomic knowledge increased. Many years after he had resigned the curatorship, it gave Keit quiet satisfaction to see that a plant which he had correctly identified was incorrectly identified by his eminent successor, John Medley Wood (Keit n.d. (b)). Before he died in 1875 , the naturalist Thomas Baines was in occasional contact with Keit (1873c).

Two problems which seriously affected Keit in his botanical studies were weak eyesight and the lack of a microscope. None the less he has the credit for publicizing Agapanthus campanulatus 'mooreanus' a dwarf flower sometimes referred to as Keit's blue lily. Another lily which carries his name is Littonia modesta var. keitii (Nelson 1984).

The role of the Durban Botanic Garden as an experimental station for various crops continued under Keit. He made full use of his new nursery. By the mid-1870's it contained: arrowroot, breadfruit, chillies, china grass, the quinine-yielding plant $\mathrm{Cin}$ chona succirubra, clove, cocoa, ginger, groundnut, indigo, khus khus, lemon grass, maize, mulberry, New Zealand flax, nutmeg, prickly comfrey, sorrel, tomatoes, turmeric, vines and yams. In addition, Keit experimented with several plantation crops. He brought in new varieties of coffee, sugar cane, tea and tobacco from Kew and distributed the seed to planters. New strains of sugar cane were especially in demand and although it was not Keit who introduced the famous uba cane he did introduce 60 new varieties into Natal from Kew and Mauritius. He also did much to encourage the growing of sugar cane. Two exotics with which Keit experimented were the opium poppy, Papaver somniferum, and the rubber plants, Ceara and Hevea braziliensis (McCracken 1985). 
Unfortunately many of the plantation species Keit promoted proved unsuitable for the Natal climate, being susceptible to disease or parasites, or too exotic in the eyes of the planters. It was in the distributing of trees that Keit made his greatest contribution. By 1877 the demand for forest trees in Natal was very great. Keit observed that even on the coast, trees were becoming more scarce and valuable every year. For firewood he recommended the planting of the silver oak, Grevillea robusta (Durban Botanic Garden 1877). He provided these on request; he also provided over 10000 plants of Eucalyptus globulus which were planted in an around Durban. These were especially used to reclaim swampy ground near the town.

In a period of seven years Keit was to distribute locally over 25000 plants and 2000 packets of seed. In this undertaking he was assisted by the Natal Government Railway Company which carried the packages from the botanic garden free of charge. Keit was disappointed in the lack of economic progress in the colony. He once wrote: 'Natal is a strange place. Everything under the sun grows here except rare tropical plants and plants from cold countries. Even so we have no industry which is indigenous, and so hardly anything is fully utilized' (Keit 1887).

As well as distributing plants and seeds within the colony Keit sent Wardian cases of indigenous Natal plants overseas, often using the official government mail bag for smaller packages. He despatched upwards of 40 Wardian cases and packages a year. He exchanged plants with the botanic gardens at Adelaide, Brussels, Calcutta, Cape Town, Glasnevin (Dublin), Grahamstown, Hamburg, Howrah, Kew, Lucknow, Madras, Melbourne, Pamplemousses (Mauritius), Pretoria and Sydney. In addition, Keit exchanged plants with five other botanical or horticultural societies and 19 nurseries or individuals overseas. One Wardian case of Encephalartos natalensis which he sent to Adelaide suprisingly survived one and a half years in a bonded store in Melbourne and was nearly three years in a dormant state before being planted out.

\section{Problems facing Keit}

Despite the sterling efforts of Keit in establishing a proper botanic garden in Durban and in winning international recognition for it, there were fundamental problems over which he had no control and which from 1876 onwards gradually undermined his work. The first of these was drought. The annual rainfall, which in 1875 had been $1372 \mathrm{~mm}$, decreased to $889 \mathrm{~mm}$ in 1876 , and stayed at this level for 1877 , before plummeting to a meagre $771 \mathrm{~mm}$ in 1878 . With only a $13,6 \mathrm{hl}$ water tank in the garden and all the watering having to be done with buckets, many plants, especially conifers and palms, soon died (Durban Botanic Garden 1878).

The second problem facing Keit was one generally experienced in Natal, that of a shortage of labour. Until 1877 he had the use of six short-sentence convicts to augment his African labour-force which fluctuated from four to seven in total. After 1877 he had the use of only three convicts, with the result that in 1879 when his African labourers left because of the Anglo-Zulu war he began employing Indian labour. So drastic was his labour crisis that Keit was often forced to do heavy manual labour himself to keep the large area of the garden under control. Though between 1875 and 1879 he had the assistance of a young German named Paul Hansch, Keit was tied to the garden by the necessity of taking twice-daily readings of the government meteorological instruments which had been installed in the garden in February 1873. As a result, Keit was prevented from going on plant-collecting expeditions which meant he had to rely on the public and on his African staff to collect on his behalf. This made him very depressed. As early as September 1873 he sent a cycad cone to Kew apologizing that he had nothing else: 'Our garden,' he explained, 'yields nothing you might care to have' (Keit 1873d).

Yet another problem facing Keit was that of the financial viability of the garden. Income rarely exceeded $£ 450$ per annum, the government grant being $£ 350$. Public subscriptions to the garden declined from $£ 62$ in 1873 to a mere $£ 17$ in 1877 due mainly to the fact that Keit became increasingly embarrassed about demanding money as he had few exotics to give subscribers in return for their subscriptions. Sales of plants in the same period, however, rose from $£ 6$ to $£ 92$ and would have been even greater had Keit been able to explore Natal and Zululand for plants. As far as expenditure was concerned, wages, rations and his own salary of $£ 150$ accounted for over $70 \%$. Money spent on building and maintenance rarely rose above $£ 50$ or $11 \%$ of expenditure.

This fatal combination of drought, labour shortage and lack of funds seriously affected the garden. By 1880 , due to lack of maintenance, the greenhouse and summer-houses had collapsed. Even the garden seats were dangerous to sit on because they were so ant-eaten. The previous year Mary Elizabeth Barber visited the Durban Botanic Garden. She wrote afterwards: "The gardens are "out of sight and out of mind"; no one appears to either think or care about them; they have a weedy and neglected appearance. The conservatory was empty ... In a pond we suddenly came upon that superb Indian water lily ( Nymphaea rubra). It was growing side by side with our own lovely blue water lily (Nymphaea stellata), and a very handsome contrast they formed; the Curator (Keit) very kindly gathered us a bunch of the former; I begged him not to pick so many, he declared that we were only too welcome to them, that no one ever came to look at them in that solitary place. We took them down to the town, where they were much admired by people who told us that they had no idea that they were growing there' (Barber 1963).

The work done by Keit in saving the garden was ignored by the public who increasingly made him the scapegoat for the inadequacies of the by now nearmoribund Horticultural Society. Keit could have gained popular support by turning the garden into a pleasure park but he refused to do this. The fact that Keit was foreign and was careful to register at least some of his children as German citizens did not en- 
dear him to some of his fellow townsfolk. Others found his quiet manner and firm personality objectionable. His successor was later to describe Keit as 'peculiar' (Wood 1882).

At the end of 1881 following a re-organisation of the horticultural society Keit resigned as curator. Writing to his cousin he merely commented: 'I could not come to terms with the rules of the new Garden's administration' (Keit 1881).

\section{Keit's later career}

William Keit did not pass into obscurity in 1881 . In 1876 he had bought a 2 ha plot adjacent to Berea Road. On this ground he built a home. With money left by his father-in-law he was also able to establish a nursery and small dairy there. He traded with overseas nurseries and, in particular, supplied large quantities of ferns of the genus Polystichum to Germany. In 1883 he was appointed curator of Durban's parks and gardens at a salary of $£ 10$ a month. With a small labour-force, one mule and a lawnmower he set about beautifying the town. He planted many trees in the streets, bamboos along Berea Road and palms along the Victoria Embankment Esplanade (Henderson 1904). His greatest achievement was properly laying out and planting Albert, Bulwer and Victoria Parks in the years between 1883 and 1885 . He also established a municipal nursery at Congella.

He died on 27 August 1916 when the First World War was at its height and anti-German feeling was prevalent in Natal (Bruss 1981). Nonetheless, Keit's contribution to Durban was not forgotten later, and a new road through his former property connecting Berea and Moore roads was named Keits Avenue.

\section{Keit's legacy}

Keit's successor was a local naturalist and farmer called John Medley Wood. Wood greatly benefited from the dissolution of the old Horticultural Society in 1883 and the establishment of a new Botanic Society to run the garden (Natal Colony 1883). He also benefited from additional government money which facilitated the employment of a Kew-trained gardener called James Wylie, and the establishment of an herbarium (Schrire 1983). The construction of a 50000 gallon reservoir by the Town Council in the grounds of the garden further eased the problems facing the Durban curator.

By the 1890s Wood, who was an excellent taxonomist, had developed the Durban Garden into the finest botanic garden in Africa. But his success was built on the foundations laid by Keit. Despite their dilapidated state, in 1881 Wood inherited a garden which was properly laid out and labelled, and which contained a large collection of plant species. Wood also inherited the goodwill which the senior staff at Kew had borne towards Keit; for the next 33 years Wood carried on a fruitful correspondence and exchange of plants with them.

Even after Keit's departure from the garden, Kew stood by him and defended him against attack (Wood 1882). In the nine years that Keit had been curator of the Durban Botanic Garden they could see no evidence to contradict the assessment of him made by Dr Moore of Glasnevin: 'I have never known a man whose moral conduct stood higher in every respect than his does, besides he is a shrewd, sensible man' (Moore 1872). Keit was a consistent man. Seventeen years earlier his employer in Basle had commented in a reference for him: 'I was impressed by his modesty and politeness and his exemplary loyalty to his profession' (Keit 1864).

\section{UITTREKSEL}

William Keit is in 1841 in Sakse/Duitsland gebore. In sy jong dae het hy deur Europa gereis en in talle bekende kwekerye gewerk. In 1872 het hy, op aanbeveling van die direkteur van Kew Gardens, na Natal geëmigreer om kurator van die Durbanse Botaniese Tuin te word. Die tuin was so vervalle dat Keit dit feitlik van die grond af weer moes opbou. Alhoewel hy grootliks in hierdie poging geslaag het, asook in die versterking van bande tussen Natal en Kew, kon hy nie die probleme van ' $n$ ernstige droogte, ' $n$ arbeidstekort en ' $n$ tekort aan fondse oorkom nie. Toe hy in 1881 uit sy pos bedank het, het hy 'n stewige fondament nagelaat waarop die beroemde plantkundige John Medley Wood voortgebou het. Later het Keit ' $n$ suksesvolle kwekery in Durban bedryf en 30 jaar lank was hy kurator van die Parke-en Tuinedepartement. In hierdie hoedanigheid het hy meer gedoen as enigiemand anders om die stad Durban te verfraai.

\section{REFERENCES}

BARBER, M. E. 1963. Wanderings in South Africa by sea and land, 1879. IV. S. Afr. Library Quart. Bull. 18: 3-17.

BRUSS, G. G. 1981. The impact of the first world war on the German communities in Natal. M. A. thesis, University of Natal, pp. 161-193.

DURBAN BOTANIC GARDENS 1873-1880. Curator's reports for the years 1873-1880. Natal Government Gazette, Natal Archives, Pietermaritzburg.

DURBAN BOTANIC GARDENS 1877. Curator's report for the year 1877. Natal Government Gazette, Natal Archives, Pietermaritzburg.

DURBAN BOTANIC GARDENS 1878. Curator's reports for the year 1878. Natal Government Gazette, Natal Archives, Pietermaritzburg.

DURBAN CITY ESTATES DEPARTMENT n.d. File reference TC15/5J636C

DURBAN TOWN COUNCIL 1883-1889. Council minutes vol. 14: 14 September 1883, 30 September 1884, 6 October 1884 and vol. 17: 7 January 1889.

HENDERSON, W. P. M. 1904. Durban: fifty years's municipal history, p. 125. Durban.

KEIT, W. 1864. Unpublished letter, 19 February 1864, referred to by G. Juiz, Basle.

KEIT, W. 1866. Unpublished letter to Hermann Steinmetz, 15 June 1866. Property of Mrs K. Plekker.

KEIT, W. 1867-1869. Unpublished letters to Hermann Steinmetz: 6 January 1867, 3 September 1868, 11 August 1869. Property of Mrs K. Plekker.

KEIT, W. 1872a. Unpublished transcript of letter to J. D. Hooker, Kew, 29 August 1872, in Strey Papers, pp. 776777 , Killie Campbell Africana Library, Durban.

KEIT, W. 1872b. Unpublished transcript of letter to J. D. Hooker, Kew, 19 December 1872, in Strey Papers, p. 778. Killie Campbell Africana Library, Durban.

KEIT, W. 1873a. Unpublished letter to D. Moore, Glasnevin, 10 January 1873, Glasnevin Botanic Gardens, Dublin.

KEIT, W. 1873b. Unpublished letter to Hermann Steinmetz, 10 January 1873. Property of Mrs K. Plekker. 
KEIT, W. 1873c. Unpublished transcript of letters to J. D. Hooker, Kew, for example, letter written 16 July 1873, in Strey Papers, p. 783, Killie Campbell Africana Library, Durban.

KEIT, W. 1873d. Unpublished transcript of letters to J. D. Hooker, Kew, 23 September 1873, and to W. T. ThiseltonDyer, Kew, 10 January 1873, in Strey Papers, pp. 784-785 and 801 respectively, Killie Campbell Africana Library, Durban.

KEIT, W. 1874. Unpublished transcript of letter to J. D. Hooker, Kew, 6 December 1874, in Strey Papers, p. 791, Killie Campbell Africana Library, Durban.

KEIT, W. 1875. Unpublished transcript of letter to J. D. Hooker, Kew, 2 September 1875, in Strey Papers, p. 796, Killie Campbell Africana Library, Durban.

KEIT, W. 1881. Unpublished letter to Wilhelm Steinmetz, 10 August 1881. Property of Mrs K. Plekker.

KEIT, W. 1887. Unpublished letter to Wilhelm Steinmetz, 2 April 1887 . Property of Mrs K. Plekker.

KEIT, W. n.d.(a). Unpublished letters to family in Dresden. Property of Mrs K. Plekker.

KEIT, W. n.d.(b). Unpublished letter to Wilhelm Steinmetz, written about 1895 . Property of Mrs K. Plekker.

KEW, ROYAL GARDENS 1881. Report on the progress and conditions of the Royal Gardens at Kew, during the year 1880 , p. 29. London.
MCCRACKEN, DONAL P. 1985. Natal's botanic gardens: their role in the colonial economy and society. Unpublished paper presented to the biennial conference of the South African Historical Society, University of Cape Town, 1985.

MOORE, D. 1872. Unpublished letter to J. D. Hooker, Kew, 27 August 1872, Glasnevin Botanic Gardens, Dublin.

NATAL AGRICULTURAL AND HORTICULTURAL SOCIETY 1848. Minute book, vol. 1, 18 April 1848, Durban Local History Museum, H1130A.

NATAL COLONY 1883. Law number 21 , to incorporate the Durban Botanic Society.

NELSON, E. CHARLES 1984. An Irish flower garden (illustrated by Wendy Walsh). Kilkenny. pp. 83-84 and 183.

SCHRIRE, D. B. 1983. Centenary of the Natal Herbarium, 1882-1982. Bothalia 14: 223-236.

STREY, R. G. 1972. The second curator of the botanic gardens, Durban, arrived 100 years ago. Natal Wildlife, November 1972 , p. 18.

STREY, R. G. 1974. William Keit. The Berea Pictorial 1,4, June 1974 , p. 12.

STREY, R. G. n.d. Notes on curators, Natal Herbarium, Durban, unpublished.

WOOD, JOHN MEDLEY 1882. Unpublished transcript of letter to W. T. Thiselton-Dyer, Kew, 8 May 1882, in Strey Papers, p. 1700, Killie Campbell Africana Library, Durban. 